\title{
HOTEL RESERVATION \\ IN A HUNGARIAN - LOCATED IN HÉVÍZ - THERMAL AND SPA HOTEL Judit POÓR ${ }^{\mathrm{a}}$, Éva TÓTH ${ }^{\mathrm{b}}$, Dávid BESENYEI ${ }^{\mathrm{c}}$
}

\author{
aDepartment of Economic Methodology, Georgikon Faculty, University of Pannonia, Deák F. Str. $16 ., 8360$ \\ Keszthely, Hungary, email: pj@georgikon.hu \\ ${ }^{b}$ Department of Economic and Social Sciences and Rural Development, Georgikon Faculty, University of \\ Pannonia, Deák F. Str. 16., 8360 Keszthely, Hungary, email: te@ georgikon.hu \\ ${ }^{\mathrm{c}}$ Economist in Tourism and Catering
}

Cite this article: Poór, J., Tóth, É., Besenyei, D. (2019). Hotel Reservation in a Hungarian Therme and Spa Hotel. Deturope. 11(1), 117-126.

\begin{abstract}
E-world is characterized by the preference for electronic options, which provides more efficient, faster and more convenient solutions than the traditional way. The emergence of the Internet restructured and made dynamic the tourism sales chain, creating the concept of e-tourism. Online tourism services have made a significant contribution to the growing popularity of individually organized trips by providing convenient and quick information, comparison and transaction opportunities.

At present, the former traditional and new, modern booking options live side by side. Based on hotel booking statistics, in our study we examine the characteristics of direct and indirect, as well as offline and modern online booking.

The proportion of direct (45.6\%) and indirect (54.4\%) bookings was balanced in the hotel, while $71.2 \%$ of reservations were connected to offline channels. It is likely, however, that online interfaces play an important role in searching and getting information - the literature also proves this.
\end{abstract}

Keywords: tourism distribution, internet, hotel room booking, consumer behavior

\section{INTRODUCTION}

The use of modern information and communication technologies (ICT) and Internet has led to revolutionarily changes in all aspects of life with starting a new marketing reality and changing the relations between market players (Monga and Kaplash, 2016). The widespread availability of the Internet and the accessibility of information and communication technology tools have been the requisites for the emergence of the present-day e-world. According to the latest data of the Hungarian Central Statistical Office (HCSO) in 2017, nearly three quarters of the Hungarian population were computer users. The number of Internet subscriptions continues to show significant growth, which is generated by the significant expansion of mobile Internet (KSH, 2015). According to the latest data of the HCSO, the number of Internet subscriptions was more than 9,8 million at the end of September 2018, which is $4,5 \%$ higher than in the same period of the previous year (KSH, 2018b). 
Poór, J., Tóth, É., Besenyei, D.

In the tourism sector, electronic communication and e-commerce has also emerged, allowing rapid and direct exchange of information and product between market players and creating new business opportunities.

\section{THEORETICAL BACKGROUND}

Online distribution channels as e-commerce platforms are virtual sales offices for hoteliers operating effectively, efficiency and budget friendly through the internet (Civak, Kaya \& Emeksiz, 2017). Consumers on the online tourism market take advantage of ease of searching, booking. Websites insure the variety of product offerings, quick price comparisons for the consumers with in a small fraction of time that is, time savings too (Toh, Raven \& DeKay, 2011).

The role of ICT in the tourism sales system has had a triple effect over time. Firstly, computer reservation systems, the so-called CRSs (Computer Reservation System) appeared in the 1970s, then the global distribution systems, the GDSs (Global Distribution System) in the 1980s, and the Internet in the 1990s (Sziva \& Nemeslaki, 2016).

The widespread use of the Internet has had a twofold, contradictory effect on tourism sales. On the one hand, the process of disintermediation meant the elimination of the intermediaries, which contributed to the increase in the share of direct sales. However, in the process of reintermediation, the rapid adaptation of intermediaries and the entry of new types of intermediaries can be observed. As a result of re-intermediation, the traditional travel businesses are also open to the Internet and have entered the 'brick and click' category, making their offers available on their websites. Besides, online travel agencies (OTAs) belong to the "click to click" category (Sziva \& Nemeslaki, 2016).

The two main types of sales forms are direct and indirect channels. In the case of a direct channel, there is a direct relationship between the tourist service provider and the consumer, while in the case of an indirect channel some intermediary contributes to deliver the product to the consumer. In the tourism of the 21th century, both direct and indirect sales can be done offline and online. The distinction between offline and online modes is not based on differences from the technical side, but on the intrinsic differences between channels. Online channels require an interface (web page) where the complete process of searching and booking takes place in one place within a standardized framework, while offline channels do not. $(\mathrm{GVH}$, 2015).

So basically, we can distinguish four typical categories of hotel reservation (Table 1). 
Table 1 Booking channels

\begin{tabular}{|l|l|l|}
\hline \multirow{2}{*}{ Online } & \multicolumn{2}{|c|}{ Distribution/Booking Channels } \\
\cline { 2 - 3 } & Direct & Indirect \\
\hline & Hotel own Website & Third-party websites: \\
& Hotel mobile application & Global Distribution Systems (GDS) \\
& Social media & Online Travel Agencies (OTAs) \\
\hline \multirow{5}{*}{ Offline } & Mail/fax & Traditional travel agencies \\
& Telephone & Tourist offices \\
& Walk-in & Trade shows, and conference \\
& Direct sales & \\
& Consumer shows & \\
\hline
\end{tabular}

Source: own edition

Global Distribution Systems (GDS) are global, but not public systems - not open to end users - that can only be used by travel agencies. Their job is to provide information and manage bookings and payments. The best known GDSs are Amadeus, Galileo, TravelPort. The first Online Travel Agency (OTA) was Expedia. The OTAs are the fastest and most dynamic forms of sales today. Online channels include websites selling packages, and services, as well as pricecomparison and opinion-gathering websites (Tripadvisor, Trivago). (Aubert, 2011; Civak, Kaya \& Emeksiz, 2017; Sziva \& Nemeslaki, 2016). Besides OTAs Masiero and Law (2016) highlights and examines the role of the Destination Marketing Organization (DMO) as a thirdparty actor.

According to Crnojevac, Gugic and Karlovcan (2010), the booking sales cycle often includes various intermediaries between the supplier (hotel) and the buyer (customer) using Web solutions. The number of intermediaries can be as high as, making the distribution more complex and expensive. Therefore, service providers must carefully choose the appropriate channel or combination of channels, not neglecting direct online channels and the use of their own website. Booking opportunities through the own website guarantee saving money on agency commissions, but make it more difficult to reach guests. At the same time tourists may also use a combination of channels organizing their own trip. Toh, DeKay \& Raven (2011) highlight that many tourists prefer to use the Internet to search for hotel rooms and successively perform the actual booking through either the Internet or by a telephone call. According to the Hungarian National Tourism Development Strategy, due to the spread of the Internet and the development of information technology, the need for online information is clearly concentrated on searching for a destination and travel organization (MTH, 2005).

At the beginning of the 2000s, foreign online accommodation booking systems began to appear on the Hungarian market. They have been followed by Hungarian ones since 2004. The market for online accommodation systems is not a regulated market, not subject to specific 
legislation, rules for e-commerce and data protection rules based on EU funds apply to it (GVH, 2015).

Online accommodation booking shows an increasing trend in Hungary, as proved by several previous research results, e. g. eNET and the Hungarian Hotel Monitor survey in 2013 (eNET, 2013). According to the data of the HCSO, the total domestic (net) accommodation income in 2012 was HUF 129 billion, of which, according to the results of the survey, about 58 billion HUF (45\%) was received via online channels. At that time $96 \%$ of the hotels had their own website, and almost all of them had an online booking site. The rate for pensions was close to $90 \%$, but in the case of apartments and guest houses, only slightly more than $60 \%$ had a web presence, each of which offered a booking option.

Based on EUROSTAT (2016) data, in 2014, Hungary had an estimated online booking rate of $64.7 \%$. According to the results of consumer research conducted by the Hungarian Competition Authority on online accommodation search and accommodation habits in 2015, $86 \%$ of travellers use the Internet to plan and organize their trip, while 59\% book their accommodation via the Internet. Hungarian travellers prefer their direct contact with the host during their domestic travel $(\mathrm{GVH}, 2015) .54 \%$ of the respondents had previously booked their accommodation via the accommodation's own website, $48 \%$ of them directly by telephone (multiple answers were allowed to this question). The third most popular channel for domestic hotel reservations - the online sites - was used by $42 \%$ of the interviewees. According to the results of the research, about one-tenth of the respondents have already booked accommodation on social media. The proportion of bookings made through traditional travel agencies is significant for foreign trips (31\%), but not significant for domestic trips (8\%). An interesting result of the research is that every second traveller uses OTAs to obtain the necessary information, but actual accommodation reservations are implemented directly (GVH, 2015).

The importance of digital technologies in tourism, providing opportunities for innovation and preparing the sector for the future is signified by the fact, that the UN World Tourism Organization (UNWTO) chose the theme 'Tourism and the digital transformation' for the last year World Tourism Day, which was celebrated in Hungary on 27 September. Implementation and development of digital tourism appears as a horizontal target in the Hungarian National Tourism Development Strategy 2030, related to which the Hungarian Digital Tourism Strategy is under development (MTÜ, 2017a).

Guest statistics are of great importance for hotels, as they can be used to analyze the characteristics of their actual guests and, at the same time, make better use of the knowledge gained to reach potential consumers more effectively. Guest statistics help businesses in future 
Poór, J., Tóth, É., Besenyei, D.

planning and developing their marketing strategy. The characteristics of the guests (gender, age, nationality), travel habits (duration of stay, booking method, number of travelers) contribute to the selection of the appropriate distribution channels. The design of the appropriate channel mix is determined by the composition of the target group, and not only by the product.

\section{DATA AND METHODS}

Although guest statistics and booking statistics are likely to overlap, we focused on booking statistics as part of the primary research in this study. Data collection took place in a Thermal and Spa hotel in Hévíz in 2017, covering 500 reservations.

We have chosen a hotel in Hévíz because Hévíz is one of the most popular destinations in Hungary for both domestic and foreign tourists. The Lake Balaton Region is the second most popular destination in Hungary, one of the main attractions of which is Hévíz. The turnover of guests at commercial accommodation also proves the fact that the Balaton Region is the second most popular resort among the guests $(1,692,124$ persons) and the number of guest nights $(5,451,600)$ after the Budapest-Central Danube Region (MTÜ, 2017b).

Based on the number of foreign guest nights, Hévíz was the second most popular town for foreigners - after the capital city, Budapest - with 697,000 foreign guest nights in 2017, and the fourth most visited town for domestic tourists (433,000 domestic guest nights) (KSH, 2018a).

In research the gender, age, nationality of the person making the reservation were examined, as well as the booking method (distinguishing direct/indirect and online/offline booking types), the guest night (reserved per person) and the number of reservations. Reservation statistics were analyzed by descriptive statistics as well as parametric and nonparametric tests.

\section{RESULTS}

The distribution of the sample according to the booking methods is shown in Figure 1. Offline booking, personal contact is the typical form in the hotel, and only $28.8 \%$ of nights are booked through online channels. However, the proportion of direct $(45.6 \%)$ and indirect $(54.4 \%)$ bookings can be considered as balanced. The reason for the higher share of indirect bookings compared to the literature is due to the high proportion of foreign guests $(85.6 \%)$ in the analysed hotel. 
Figure 1 Distribution of the sample according to the booking methods

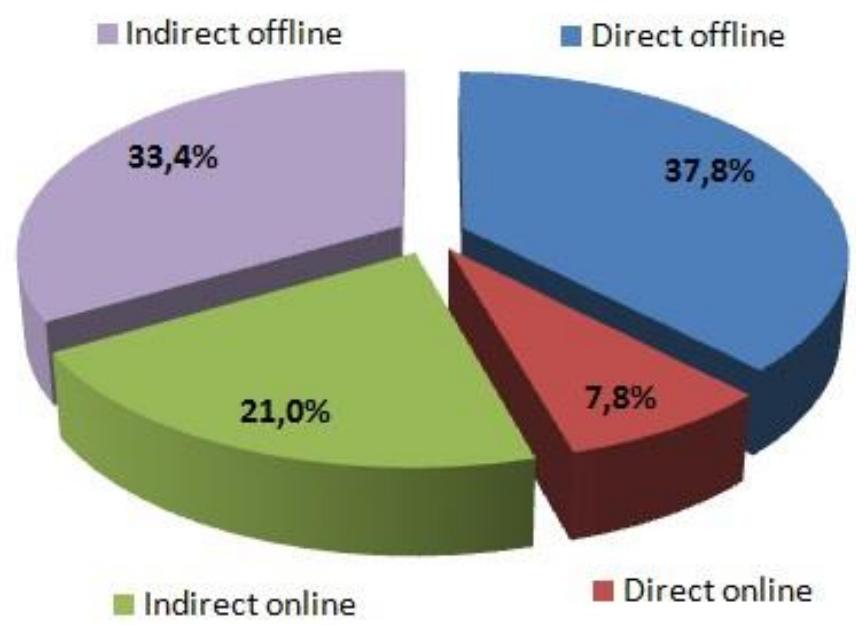

Source: own edition

In the hotel, guests book accommodation in many ways from direct options to OTA portals to traditional travel agencies. The most popular OTA is booking.com (16.8\%). Among travel agencies Robinson Tours delivers the most tourists (5.2\%). This company organizes tours mostly from Russia and Ukraine to Hévíz.

Examining the proportion of domestic and foreign travel agencies within the indirect online and offline category, the results are the following: while the share of foreign OTAs in booking is $20 \%$, that of domestic ones is practically negligible (1\%). In traditional travel agencies, the share of foreigners is also decisive (24.6\%) compared to domestic ones (8.8\%), but this is probably due to the domination of the hotel and thus the dominance of foreigners.

Distinguishing domestic and foreign reservations (Table 2), it can be clearly seen that domestic ones (73.6\%) are characterized by direct offline booking. Nearly a fifth of all reservations is indirect online booking, ie booking via OTA. In the case of foreign bookings, offline booking methods are the primary ones (direct 31.8\%, indirect 38.6\%), and indirect online hotel booking $(21.7 \%)$ also shows a higher rate compared to domestic hotel registrants.

Table 2 Share of the different booking methods in the analysed hotel in Hévíz

Source: own calculation

\begin{tabular}{|l|c|c|c|c|c|}
\hline \multirow{2}{*}{} & \multicolumn{2}{|c|}{ Direct } & \multicolumn{2}{c|}{ Indirect } & \multirow{2}{*}{ Total } \\
\cline { 2 - 5 } & offline & online & online & offline & \\
\hline Domestic & $\mathbf{7 3 . 6 \%}$ & $6.9 \%$ & $16.7 \%$ & $2.8 \%$ & $100 \%$ \\
\hline Foreign & $\mathbf{3 1 . 8 \%}$ & $7.9 \%$ & $21.7 \%$ & $\mathbf{3 8 . 6 \%}$ & $100 \%$ \\
\hline
\end{tabular}

The results of the $\chi^{2-t e s t}$ shows that there is a significant relationship between the nationality and the booking method $(\mathrm{p}=0.000)$ as well as between the gender and the booking method ( $\mathrm{p}$ 
$=0.033$ ). The share of males is significantly higher in the case of direct online (booking via hotel own website), while the share of females is relatively higher in case of indirect offline options (traditional travel agency) (Table 3).

Table 3 Share of the gender by different booking methods

\begin{tabular}{|l|c|c|c|c|}
\hline \multirow{2}{*}{} & \multicolumn{2}{|c|}{ Direct } & \multicolumn{2}{c|}{ Indirect } \\
\cline { 2 - 5 } & offline & online & online & offline \\
\hline Males & $\mathbf{6 7 . 2 \%}$ & $\mathbf{7 9 . 5 \%}$ & $\mathbf{6 5 . 7 \%}$ & $56.9 \%$ \\
\hline Females & $\mathbf{3 2 . 8 \%}$ & $20.5 \%$ & $\mathbf{3 4 . 3 \%}$ & $\mathbf{4 3 . 1 \%}$ \\
\hline Total & $100 \%$ & $100 \%$ & $100 \%$ & $100 \%$ \\
\hline
\end{tabular}

Source: own calculation

Regarding the central location measures of reserver's age (Table 4), it can be clearly seen that the mean (51-52 years) and median (48-50) values are almost the same in the case of the direct and indirect online, as well as indirect offline channels. Independent-Samples t-tests testing the significance of the difference between two sample means, confirm this. The mean of reserver's age of direct offline bookings is slightly higherthan that of other booking methods.

Table 4 Central location measures (mean and median) of reserver's age and the results of the t-test

\begin{tabular}{|l|c|c|c|c|}
\hline & \multicolumn{2}{|c|}{ Direct } & \multicolumn{2}{c|}{ Indirect } \\
\hline & offline & online & online & offline \\
\hline Mean & 56.58 & 51.95 & 50.61 & 51.37 \\
\hline Median & 57 & 50 & 50 & 48 \\
\hline
\end{tabular}

\begin{tabular}{|l|c|c|c|}
\hline $\mathrm{p}$ value & Direct - online & Indirect - online & Indirect - offline \\
\hline Direct - offline & 0.080 & $\mathbf{0 . 0 0 0}$ & $\mathbf{0 . 0 0 2}$ \\
\hline Direct - online & - & 0.588 & 0.835 \\
\hline Indirect - online & & - & 0.668 \\
\hline
\end{tabular}

Source: own calculation

Because of lack of normality - thanks to partly the outliers - Median test was applied to analyze the significance of the difference in the reservation number. There is no significant difference $(p=0,223)$ in the number of reservations, typical and middle values are 2 for each category.

Table 5 Central location measures (mean and median) of reservation number

Source: own calculation

\begin{tabular}{|l|c|c|c|c|}
\hline & \multicolumn{2}{|c|}{ Direct } & \multicolumn{2}{c|}{ Indirect } \\
\hline & offline & online & online & offline \\
\hline Mean & 2.03 & 1.82 & 1.80 & 2.05 \\
\hline Median & 2 & 2 & 2 & 2 \\
\hline
\end{tabular}


Because of lack of normality Median test was also applied in the case of the night reserved per person to test the significance of the difference. There are significant differences $(p=0.018)$ between the channels in terms of nights reserved per person. On the basis of the Mann-Whitney test results reservations booked through traditional travel agencies (indirect offline) provide a significantly higher $(\mathrm{p}=0.048)$ stay compared to bookings made through OTAs (Figure 2). There is no significant difference between the central location measures of other categories. Regarding the histogram of reserved nights, it is clear that travel agents sell package tours, the number of one-day and one-and-two-week bookings is high (Fig. 2).

Figure 2 Histograms with the central location measures (average and median) of the night reserved per person

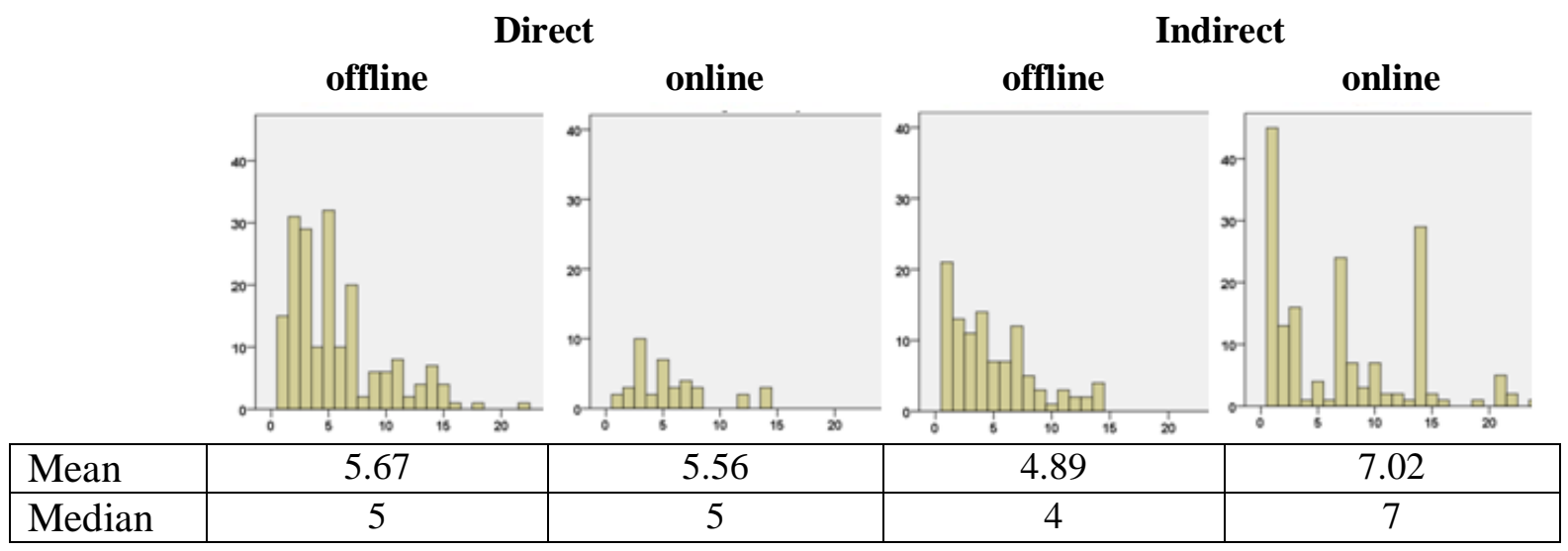

\begin{tabular}{|l|c|c|c|}
\hline $\mathrm{p}$ value & Direct - online & Indirect - online & Indirect - offline \\
\hline Direct - offline & 0.734 & 0.104 & 0.480 \\
\hline Direct - online & - & 0.198 & 0.739 \\
\hline Indirect - online & & - & $\mathbf{0 . 0 4 8}$ \\
\hline
\end{tabular}

Source: own calculation

\section{CONCLUSION}

Online booking of hotels has an increasing tendency in the world as well as in Hungary. Based on EUROSTAT data, the estimated online hotel booking rate was $64.7 \%$ in 2014 in Hungary. According to the results of consumer research conducted by the Hungarian Competition Authority on online accommodation search and accommodation habits in 2015, $86 \%$ of Hungarian travelers use the Internet to plan and organize their travel and $59 \%$ book their accommodation via the Internet. The first three of the most popular and nearly equally mentioned booking methods are the website of the hotel, the direct telephone and an intermediary's webpage. 
Poór, J., Tóth, É., Besenyei, D.

In our primary research, direct booking was the most important way for domestic reservers (nearly three quarters of bookings). The share of the OTAs was a remarkable 17\%. The hotel's own website had a $7 \%$ share. In the case of foreigners, the role of the hotel's own website was also not decisive (8\%), while traditional travel agencies (nearly $40 \%$ ) and direct offline registration (around 30\%) were of great importance. The weight of bookings made at OTA is almost the same for domestic and foreign bookings, accounting for nearly one fifth of all reservations.

Overall, the proportion of direct (45.6\%) and indirect (54.4\%) bookings is balanced, while $71.2 \%$ of reservations are linked to offline channels. Probably, online interfaces play an important role in searching and getting information, but not so much on making the actual reservation.

Our analysis highlights that bookings through traditional travel agencies provide a higher average stay. Most of the bookings were done by men. This rate is especially high for registrations via the hotel's own website, nearly $80 \%$. The hotel has an interest in its own sales, and the future task is to increase the proportion of sales through its own website.

The examined destination, Hévíz, has specific characteristics:

- one of Hungary's most popular destinations for both domestic and foreign tourists,

- one of the most important thermal tourism destination with typically higher age guests and higher duration stay,

- however, there is a significant competition among the hotel owners, so it is very important for them to have an online experience (they can also serve as an example for other destinations).

Our future research goal is to study the booking characteristics of several accommodation types in Hévíz, on the one hand, and to compare the booking characteristics with other - thermal and non thermal - hotels.

\section{REFERENCES}

Aubert A. (lead author) (2011). Turizmus-menedzsment, Pécsi Tudományegyetem, Pécs. [In Hungarian, Tourism Management]

Civak, B., Kaya, E., \& Emeksiz, M. (2017). Online distribution channels and yield management in the hotel industry. In: Gursoy, D. The Routledge Handbook of Hospitality Marketing. Routledge, New York pp: 210-223.

Crnojevac, I.H., Gugic, J., \& Karlovcan, S. (2010). eTourism: A comparison of Online and Offline Bookings and the Importance of Hotel Attributes. Journal of Information and Organizational Sciences JIOS, 34(1), 41-54

eNET (2013). Az eNET és a Magyar Hotel Monitor kutatásának eredményei. 
http://www.enet.hu/hirek/a-szallasfoglalas-csaknem-fele-interneten-tortenik/

Hungarian, Results of eNET and Magyar Hotel Monitor research]. Accessed: on March $6^{\text {th }} 2019$.

EUROSTAT (2016). Statistics on ICT use in tourism.

http://ec.europa.eu/eurostat/statistics-explained/index.php/Statistics_on_ICT_use_in_tourism Accessed: on March $6^{\text {th }} 2019$.

GVH (2015). Ágazati vizsgálat az online szálláshelyfoglalás piacán. Jelentés tervezet. Gazdasági Versenyhivatal, Budapest. [In Hungarian, Sectorial examination on the online hotel booking market]

KSH (2015). Infokommunikációs (IKT-) eszközök és használatuk a háztartásokban és a vállalkozásokban, 2014. Központi Statisztikai Hivatal, Budapest. [In Hungarian, Information and communication technologies (ICT) and their use in households and businesses, 2014]

KSH (2018a). Helyzetkép a turizmus, vendéglátás ágazatról, 2017. Központi Statisztikai Hivatal. Budapest. [In Hungarian, Tourism, catering, 2017]

KSH (2018b). Távközlés, internet, televíziószolgáltatás, 2018. III. negyedév Statisztikai Tükör 2018. december 10. [In Hungarian, Telecommunications, Internet, Television, 2018. III. quarter]

Masiero, L., \& Law, R. (2016). Comparing reservation channels for hotel rooms: A behavioral perspective. Journal of travel \& tourism marketing, 33(1), 1-13.

Monga, N., \& Kaplash, S. (2016) To study consumer behaviour while booking hotel through online sites International Journal of Research in Economics and Social Sciences Vol. 6 Issue: 5, pp. 158-164

MTÜ (2017a). Nemzeti Turizmusfejlesztési Stratégia 2030, Magyar Turisztikai Ügynökség. Budapest. [In Hungarian, National Tourism Development Strategy 2030]

MTÜ (2017b). Riport a rekordévről, turizmus Magyarországon 2016 Magyar Turisztikai Ügynökség. Budapest. [In Hungarian, Report on record year, tourism in Hungary 2016]

MTH (2005). Nemzeti Turizmusfejlesztési Stratégia 2005-2013, Magyar Turisztikai Hivatal, Budapest. [In Hungarian, National Tourism Development Strategy 2005-2013]

Sziva I., \& Nemeslaki A. (2016). Utazás E-Világban. Internet és versenyképesség a turizmusban. Információs Társadalomért Alapítvány. Budapest. [In Hungarian, Traveling in E-World. Internet and competitiveness in tourism.]

Toh, R. S., Raven, P. V., \& DeKay, F. (2011). Selling Rooms: Hotels vs. Third-Party Websites Cornell Hospitality Quarterly 52(2), 181-189 